\title{
BMJ Open Scoping review to map evidence on mechanism of action, pharmacokinetics, effectiveness and side effects of centchroman as a contraceptive pill
}

\author{
Rita Kabra, ${ }^{1}$ Komal Preet Allagh (D) , ${ }^{2}$ Moazzam Ali (D) , \\ Chandani Anoma Jayathilaka, ${ }^{3}$ Kasonde Mwinga, ${ }^{4}$ James Kiarie ${ }^{1}$
}

To cite: Kabra R, Allagh KP, Ali M, et al. Scoping review to map evidence on mechanism of action, pharmacokinetics, effectiveness and side effects of centchroman as a contraceptive pill. BMJ Open 2019;9:e030373. doi:10.1136/ bmjopen-2019-030373

- Prepublication history for this paper is available online. To view these files, please visit the journal online (http://dx.doi. org/10.1136/bmjopen-2019030373).

Received 11 March 2019 Revised 27 August 2019 Accepted 02 September 2019

Check for updates

(C) Author(s) (or their employer(s)) 2019. Re-use permitted under CC BY-NC. No commercial re-use. See rights and permissions. Published by BMJ.

${ }^{1}$ Department of Reproductive Health and Research, World Health Organization, Geneva, Switzerland

${ }^{2}$ Consultant, World Health Organization, Geneva,

Switzerland

${ }^{3}$ Department of Family Health, Gender and Life course, World Health Organization Regional Office for South-East Asia, New Delhi, India

${ }^{4}$ World Health Organization Country Office for India, New Delhi, India

Correspondence to Dr Komal Preet Allagh; komal.allagh@gmail.com

\section{ABSTRACT}

Objective To systematically identify and map the available evidence on effectiveness, side effects, pharmacokinetics and mechanism of action of centchroman as a contraceptive pill.

Introduction Centchroman was introduced in the Indian national family planning programme in 2016 as a oncea-week short-term contraceptive pill/oral contraceptive. At present there are no WHO recommendations on this method of contraception. We examined the available evidence through a scoping review.

Methods A search was conducted inclusive to the years 1970-2019 on electronic databases, grey literature sources and reference lists of included studies to identify studies. The five stages of Arksey and 0'Malley's scoping review framework were applied in undertaking this scoping review.

Results The review identified 33 studies conducted between 1976 and 2017. Two studies reported mechanism of action of centchroman. Pharmacokinetics was reported by five studies among non-breastfeeding women and four studies among breastfeeding women. Eight studies reported on effectiveness ranging from $93 \%$ to $100 \%$. Pregnancies due to user failure ranged from $2.6 \%$ to $10.2 \%$. Although side effects were reported in 13 studies, the incidence varied greatly between the studies. Continuous bleeding and prolonged cycles $>45$ days were the most commonly reported side effects. All studies conducted had a small sample size and the duration of follow-up of women was 12 months or less. Fifty-five per cent of studies were by the developers of the pill (Central Drug Research Institute) and results of the phase IV clinical trial were unavailable.

Conclusions The scoping review shows that studies with robust designs and conducted in international context are lacking. Insufficient evidence exists on centchroman use as a postcoital contraceptive pill. The broad uncertainty in range of side effects and effectiveness in the studies implies insufficient evidence to make global recommendations on centchroman that is currently licensed as a contraceptive in India.

\section{INTRODUCTION}

Centchroman acts as a selective oestrogen receptor modulator with tissue selective
Strengths and limitations of this study

- Strength of our study is that it is the first scoping review to explore the mechanism of action, pharmacokinetics, effectiveness and side effects of centchroman, when used as a weekly or postcoital contraceptive pill.

- A limitation of our review is that we are likely to have missed studies on mechanism of action of centchroman since animal studies were excluded from the review.

- All identified studies in this scoping review were from India. Additionally, roughly half of the studies in this review were published from the developers of the drug (Central Drug Research Institute).

- There is no detailed drug trial on use of centchroman as a postcoital contraceptive pill.

- Studies on side effects of centchroman as a contraceptive pill are limited by small sample size, short duration of follow-up and the fact that all studies have been conducted in India.

oestrogenic or antiestrogenic effects. ${ }^{1}$ It suppresses the oestrogen receptors in the reproductive organs, but stimulates those of other organs like the bones. ${ }^{12}$ It is used as a contraceptive pill/oral contraceptive and in treatment of dysfunctional uterine bleeding, mastalgia and fibroadenoma due to its oestrogen antagonist effect. ${ }^{3}$ Due to its oestrogen agonist effect, centchroman is used for management of osteoporosis and its levoisomer has been shown to have some cardioprotective effects. ${ }^{3}$ The reported advantages of centchroman over other contraceptive pill/oral contraceptives are: (1) it is taken once a week; (2) it does not have any side effects seen with hormonal pills like nausea, vomiting and weight gain; (3) it is considered safe for use among breastfeeding women ${ }^{4}$; and (4) it can be taken by women of all ages.

In the 1960s, the Government of India called on Indian laboratories to develop alternate 
birth control pills. The team at Central Drug Research Institute (CDRI) took up this challenge and synthesised ${ }^{35}$ centchroman (3,4-trans-2,2-dimethyl-3-phenyl-4-p ( $\beta$-pyrrolidinoethoxy)-phenyl-7-methoxychroman) in $1967 .{ }^{36}$ Since it was made at CDRI and belongs to the chroman family, it was named as centchroman. In 1994, centchroman was given an international non-proprietary name as ormeloxifene. ${ }^{7}$ Following preclinical and clinical studies (phase 1 and 2) in 1989 the Drug Controller General of India approved centchroman as a contraceptive pill/oral contraceptive in $1991 .{ }^{36}$ It was available in the Indian market since 1992. It was first manufactured by Torrent Pharmaceuticals, Ahmedabad, and marketed under brand name Centron. Later, Hindustan Latex Limited (HLL) Lifecare, Thiruvananthapuram, manufactured it under the brand names Choice-7 and Saheli. ${ }^{8}$ The Ministry of Health and Family Welfare, India, has distributed centchroman at a subsidised cost since 1995 (social marketing scheme). ${ }^{36}$

In 2008, HLL Lifecare entered the international market by launching centchroman as a postcoital pill under the brand name Ivyfemme in Peru, South America. ${ }^{9}$ However, in 2010 the licence to sell the pill was revoked by Peru's Directorate General of supplies and drugs. The reason given for this was that the pill acted by preventing implantation of a fertilised egg and sale of any abortifacient drug was considered illegal in Peru. ${ }^{9}$ In 2013, HLL Lifecare launched centchroman as a postcoital pill in India under the brand name Tatkal-72. ${ }^{10}$ The production of Tatkal-72 was discontinued in 2014 due to restrictions on marketing and advertising of emergency contraceptive pills in India.

The Ministry of Health and Family Welfare, India, in April 2016 decided to expand oral contraceptive options by including centchroman in the national family planning programme under the brand name Chhaya. ${ }^{4} 11$ Chhaya is available to women through the public delivery system free of cost. Oral contraceptives that are safe among breastfeeding women have a better potential to improve the use of family planning methods by postpartum women, hence centchroman was included in the national family planning programme. Figure 1 depicts the key milestones in the evolution of centchroman in India.
In this review we have focused on the use of centchroman as an contraceptive pill/oral contraceptive (weekly pill and postcoital pill). As a weekly contraceptive pill, the recommended dosage of centchroman is a $30 \mathrm{mg}$ pill twice a week for 12 weeks, followed by a $30 \mathrm{mg}$ pill once a week. ${ }^{45}$ Centchroman as an emergency postcoital pill is taken as a $60 \mathrm{mg}$ dose within 72 hours of intercourse. ${ }^{12}$

We are conducting this scoping review to determine the scope/coverage of the body of literature on effectiveness, safety, pharmacokinetics and mechanism of action of centchroman as a contraceptive pill (weekly and postcoital). This review will identify and map the types of available evidence on centchroman as a contraceptive pill and determine any knowledge gaps.

\section{Aims and objectives}

This scoping review aims to systematically include the entire range of published and grey literature on:

- Extent and type of evidence on effectiveness and side effects of using centchroman as a contraceptive pill (weekly and postcoital pill).

- Extent of evidence on mechanism of action of centchroman when used as a contraceptive in women.

- Extent of evidence on pharmacokinetics of centchroman among both non-lactating and breastfeeding women.

\section{METHODS}

A protocol for this scoping review was developed a priori using the Arksey and O'Malley York's five-stage framework. ${ }^{13}$ The five steps of the scoping review were: (1) identifying the research question; (2) identifying the search strategy; (3) study selection; (4) data charting; and (5) collating, summarising and reporting the results.

\section{Step 1: identification of the research question}

This scoping review was conducted to answer the following primary research question: What is the current state of evidence on effectiveness and side effects of centchroman as a contraceptive pill (weekly pill and postcoital pill)? The secondary research questions were: What is current available evidence on mechanism of action of centchroman in women?

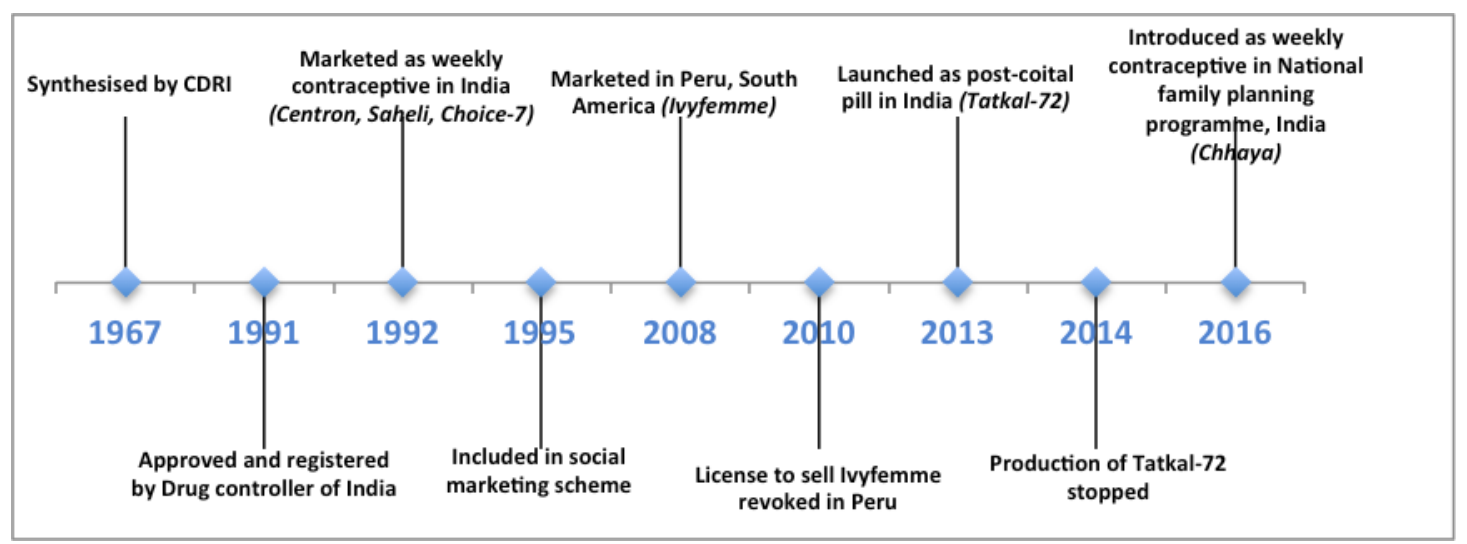

Figure 1 Key milestones on evolution of centchroman. CDRI, Central Drug Research Institute. 
What is current evidence on pharmacokinetics of centchroman in breastfeeding women and non-lactating women?

\section{Step 2: identification of relevant studies (search strategy)}

To address the research questions, we developed a detailed search strategy to identify all relevant publications on centchroman. The following Medical Education Subject Headings terms were identified and used: centchroman, ormeloxifene, saheli, safety, pharmacokinetics, effectiveness, efficacy and mechanism of action. Using the search terms, we systematically searched the following electronic databases for studies published from 1970 up to 27 July 2017: MEDLINE, EMBASE, INDMED, Cochrane Library and Google Scholar. The search was most recently rerun on 23 January 2019 (no new studies added).

No limits were placed on the searches. An example of the search strategy in EMBASE is given as follows: "centchroman'/exp OR '1 [2 [4 (7 methoxy 2, 2 dimethyl 3 phenylchroman $4 \mathrm{yl}$ ) phenoxy] ethyl] pyrrolidine':ti,ab,de OR '2, 2 dimethyl 3 phenyl 4 [4 (2 pyrrolidinoethoxy) phenyl] 7 methoxychroman':ti,ab, de OR '3, 4 trans 2, 2 dimethyl 3 phenyl 4 [4 (2 pyrrolidinoethoxy) phenyl] 7 methoxychroman':ti,ab, de OR '7 methoxy 2, 2 dimethyl 3 phenyl 4 [4 (2 pyrrolidin 1 ylethoxy) phenyl] chroman':ti,ab, de OR 'centron':ti, ab, de OR 'choice 7':ti,ab, de OR 'levormeloxifene':ti,ab, de OR 'ormeloxifene':ti,ab, de OR 'saheh':ti,ab, de OR 'saheli':ti,ab, de OR 'shaeli':ti,ab, de OR 'trans 2, 2 dimethyl 3 phenyl 4 [4 (2 pyrrolidinoethoxy) phenyl] 7 methoxychroman':ti,ab,de OR 'centchroman':ti, ab, de OR '31477-60-8':rn”.

Furthermore, websites such as CDRI, Indian Council of Medical Research (ICMR), Clinical Trials Registry-India, WHO and Popline were searched for studies and scientific reports on centchroman. We searched websites of two major drug authorities, Food and Drug Administration and European Medicines Agency, and found no information on the relationship of ormeloxifene/centchroman and oral contraceptives were available on these websites. In addition, we searched for conference proceedings, and student master's and $\mathrm{PhD}$ thesis. The reference lists of all the retrieved studies were searched to identify any additional studies of relevance. We contacted authors to provide studies and additional information that was unavailable.

\section{Step 3: selection of studies for review}

We included studies from 1970 to present (2019), to reflect the period during which centchroman was first synthesised and drug trials initiated. No limits were placed on language and location of study. We included studies on women using centchroman only as a contraceptive pill (weekly pill or emergency postcoital pill). Table 1 depicts the eligibility criteria.

After running the search, all the retrieved studies were exported into EndNote X7 reference management software. The EndNote program was used to check for duplication. The study selection process consisted of two levels of screening:

1. Title and abstract review: Two reviewers (RK, KPA) independently screened the title and abstract of all the retrieved citations for inclusion guided by the eligibility criteria. An article that was considered relevant by either or both the reviewers was included for full-text review, and any discrepancies were resolved through discussion. Full-text articles that were excluded at the screening stage had reasons for exclusions documented.

2. Full-text review: In the second step, the reviewers (RK, KPA) independently assessed the full-text articles to determine if they met the inclusion and exclusion criteria. Any disagreement was resolved by mutual discussions between the reviewers. For included studies, two authors (RK, KPA) extracted the data using the data-charting sheet.

\section{Step 4: charting the data}

A data-charting sheet was designed in Microsoft Excel to extract the general characteristics of each study. Information retrieved included study characteristics (authors, country, region, year published, study aim, study design, number of participants) and key research topics (side effects, effectiveness, mechanism of action or pharmacokinetics of centchroman). For each research topic separate data-charting sheets were used to extract relevant information from each included study. The data-charting sheets were constantly updated through the review process.

\begin{tabular}{lll}
\hline Table 1 & Inclusion/exclusion criteria & \\
\hline Criteria & Inclusion & Exclusion \\
\hline Study design & $\begin{array}{l}\text { Quantitative, qualitative and mixed methods study, systematic } \\
\text { review }\end{array}$ & Studies on animals, narrative review \\
Location & Any country & None \\
Date & 1970 to present (2019) & Before 1970 \\
Language & All languages & None \\
$\begin{array}{l}\text { Research } \\
\text { focus }\end{array}$ & $\begin{array}{l}\text { Main focus on safety, side effects, effectiveness, mechanism of } \\
\text { action and pharmacokinetics when used as a contraceptive }\end{array}$ & $\begin{array}{l}\text { Main focus on non-contraceptive uses of } \\
\text { centchroman }\end{array}$ \\
type & $\begin{array}{l}\text { Case reports, scientific reports, primary research article, } \\
\text { systematic reviews, commentaries, letter to editors, conference } \\
\text { proceedings, master's and PhD thesis }\end{array}$ & $\begin{array}{l}\text { Narrative reviews, newspaper and magazine } \\
\text { articles }\end{array}$ \\
\hline
\end{tabular}




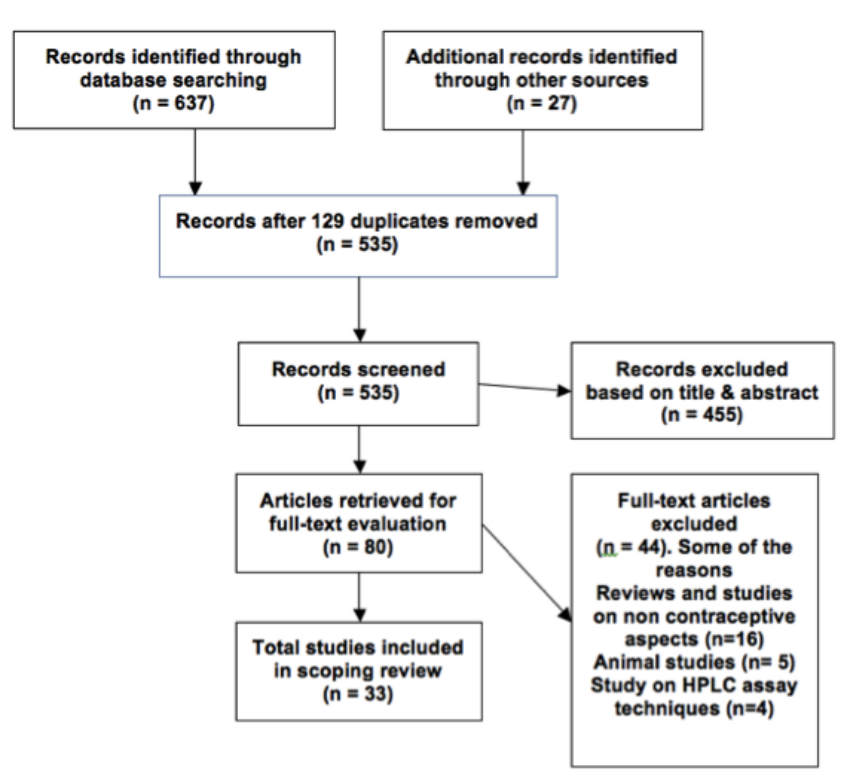

Figure 2 Preferred Reporting Items for Systematic Reviews and Meta-Analyses (PRISMA) flow chart. HPLC, highperformance liquid chromatography.

\section{Step 5: collating, summarising and reporting the results}

To summarise the findings for this scoping review, each author repeatedly reviewed the extracted evidence independently. The extracted data were summarised based on the individual research questions and around the following outcomes: effectiveness and side effects when used as a weekly or postcoital contraceptive pill, and mechanism of action as contraceptive pill in women and pharmacokinetics of centchroman in non-lactating women and in breastfeeding women. The data extracted from the data-charting sheet were analysed descriptively (frequencies and percentages) to facilitate categorisation, charting and discussion. Scoping reviews aimed to identify, map findings and to provide an overview of the available literature in the topic area rather than an assessment of study quality. ${ }^{14}$

\section{Patient and public involvement}

Patients and public were not involved in this review.

\section{RESULTS}

Of the 664 articles initially identified by our search criteria, only 33 met the inclusion criteria for this scoping review (figure 2). Of these 33 studies, 21 (64\%) were experimental (20 non-randomised clinical trials and 1 randomised controlled trial (RCT)), 4 (12\%) were observational (descriptive studies), 3 (9\%) were case reports, 3 $(9 \%)$ were national guidelines and $2(6 \%)$ were annual reports.

We identified 8 studies on effectiveness of centchroman as a weekly contraceptive pill, 1 study on effectiveness of centchroman as a postcoital pill, 13 studies on side effects of centchroman (weekly and postcoital pill), 2 on mechanism of action in women and 12 studies on pharmacokinetics among non-lactating and breastfeeding women.
All studies were conducted in India and reported in English. The earliest study was published in 1976 and the latest in 2017. The full texts of studies were available for all except one study for which only the abstract was available. ${ }^{15}$ Research publications on centchroman have increased in frequency in the recent years with $39.4 \%$ of studies published in the last 10 years (2007-2017) and $60.6 \%$ in the previous 30-year period (1976-2006). Roughly half $(54.5 \%)$ of the studies were published from the developers of the pill (CDRI), and all were clinical trials. The general characteristics of the included studies are detailed in table 2 .

\section{Mechanism of action of centchroman}

Two clinical trials in our review report the mechanism of action of centchroman among women. ${ }^{16}{ }^{17}$ The first study was conducted among eight women with ovulatory failure. The women were non-randomly allocated into one of three treatment arms, where centchroman was administered in doses of 15,30 or $60 \mathrm{mg}$ daily for 10-20 days. ${ }^{16}$ Increased levels of plasma progesterone, urinary pregnanediol and oestrogen were observed reflecting that centchroman stimulates the pituitary ovarian axis. The authors concluded that centchroman could induce ovulation in anovulatory women. The second study was conducted among 10 healthy women, non-randomly allocated into two groups. Six women received $120 \mathrm{mg} /$ week and four women received $60 \mathrm{mg} /$ week schedule for 2 months. Increase in cycle length was noticed in all cases probably due to lengthening of the follicular phase. The authors concluded that centchroman at the mentioned doses does not seem to inhibit ovulation although it may delay it; it exerts its contraceptive effect mainly due to its action on cervical mucus and endometrial affecting sperm transport and implantation. ${ }^{17}$

Animal studies demonstrated that centchroman acts by increasing the speed of transport of the zygote through the fallopian tubes, so that it reaches the uterus early. Second, it accelerates blastocyst formation, so that it is hypermature when it reaches the endometrium and fails to implant. Lastly, it acts by inhibiting endometrial receptivity to blastocyst signals and by suppressing endometrial proliferation and defective endometrial decidualisation, so that it is not adequately prepared to receive a fertilised egg when it reaches the uterus. ${ }^{24618}$

\section{Pharmacokinetics of centchroman}

In non-lactating women

Five clinical trials conducted by CDRI report the pharmacokinetics of centchroman in non-lactating women. ${ }^{15}$ 19-22 Of these, two trials report pharmacokinetics after administration of single $30 \mathrm{mg}$ dose of centchroman, ${ }^{20}{ }^{21}$ blood samples were collected at regular intervals up to 672 hours after drug administration in both, one trial reported pharmacokinetics following administration of single $60 \mathrm{mg}$ dose, blood samples were collected at regular intervals up to 504 hours after drug administration $^{19}$ and one trial described pharmacokinetics after 


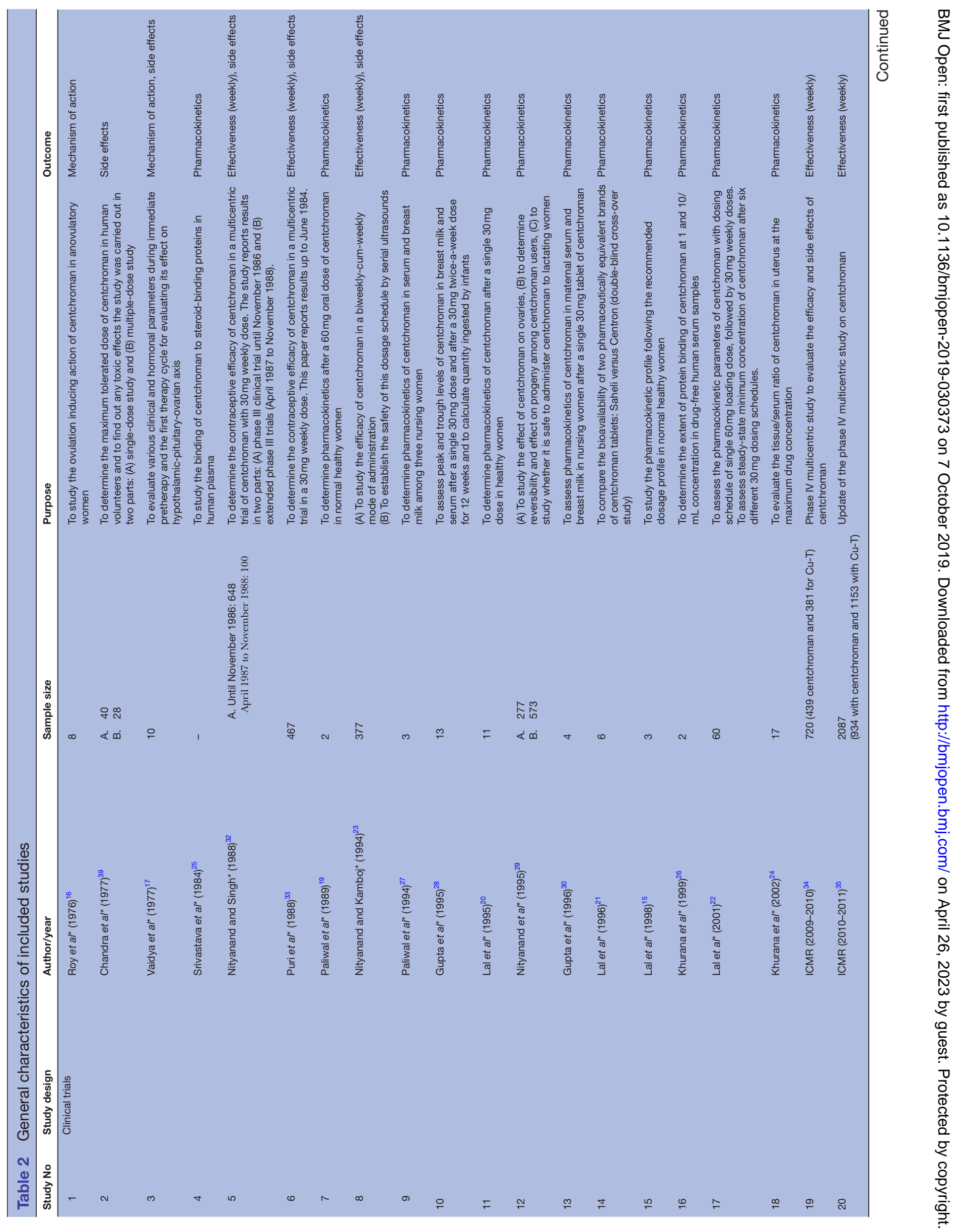




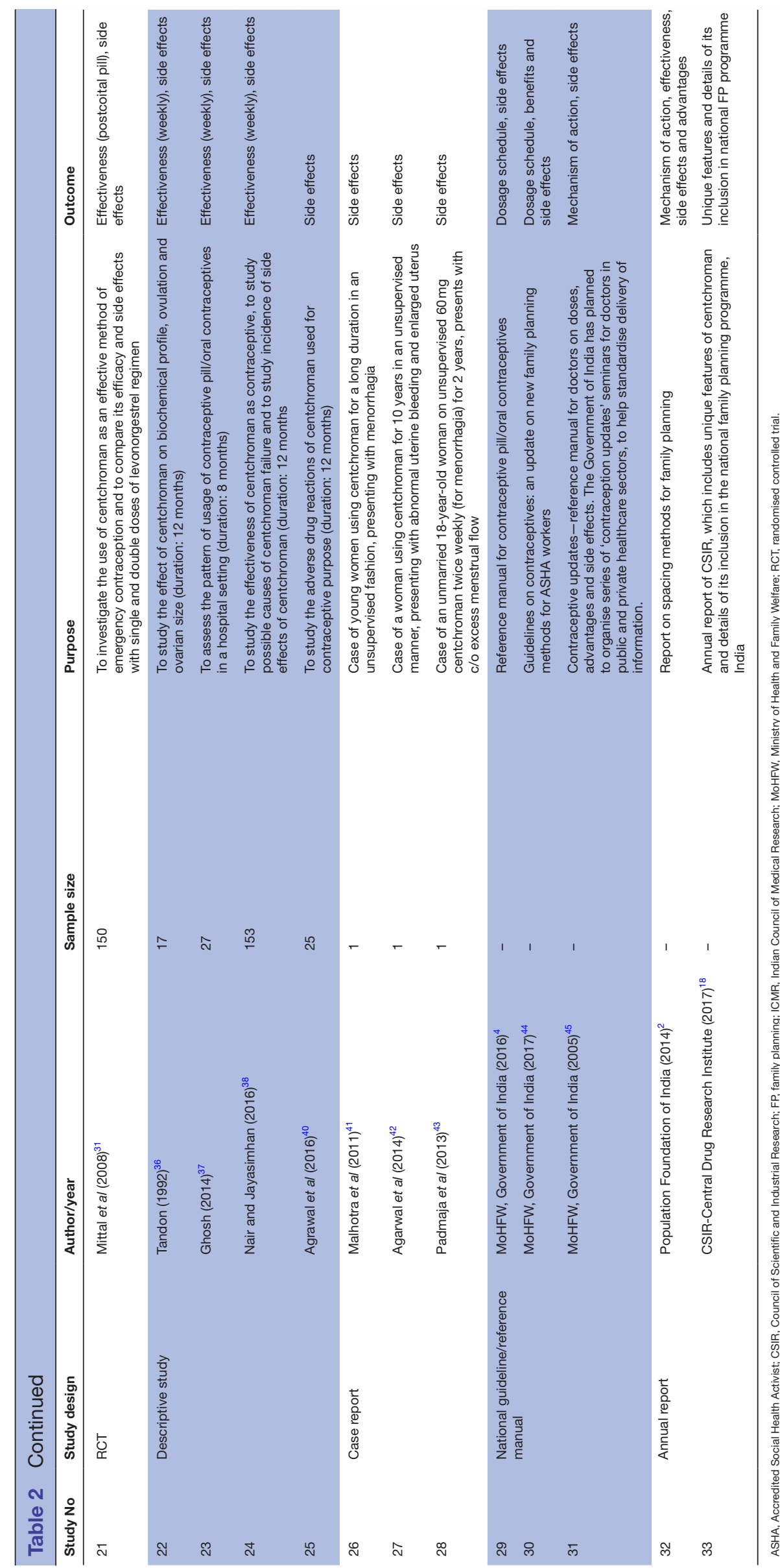


$60 \mathrm{mg}$ loading dose followed by $30 \mathrm{mg}$ weekly dose. ${ }^{22} \mathrm{In}$ addition, one trial reported pharmacokinetics following administration of $30 \mathrm{mg}$ biweekly for 12 weeks (only study abstract available) ${ }^{15}$

The peak serum concentration $\left(\mathrm{C}_{\text {max }}\right)$ of centchroman was reported by three of these studies. ${ }^{152022} \mathrm{C}_{\max }$ following a $30 \mathrm{mg}$ dose is nearly half $(55.5 \pm 14.5 \mu \mathrm{g} / \mathrm{L})$ of that observed with a $60 \mathrm{mg}$ dose, indicating $\mathrm{C}_{\max }$ is dose dependent. ${ }^{20}$ The time taken to reach the peak $\left(\mathrm{T}_{\max }\right)$ following $30 \mathrm{or} 60 \mathrm{mg}$ dose was between 4 and 8 hours. In the multiple dose study, it was noted that $\mathrm{C}_{\max }$ was the same after a single $30 \mathrm{mg}$ dose $(55 \pm 14.2 \mathrm{ng} / \mathrm{mL})$ and repeated dosing did not alter the $\mathrm{C}_{\max }(62.4 \pm 11.9 \mathrm{ng} / \mathrm{mL})$ or $\mathrm{T}_{\max }(6$ hours $) .{ }^{15}$ This indicated that there was no accumulation of centchroman in the body with repeated doses.

The steady-state minimum concentration of centchroman $\left(\mathrm{C}_{\min }\right)$ was reported in two studies. ${ }^{22} 23$ The $\mathrm{C}_{\min }$ following single $30 \mathrm{mg}$ dose was $16 \mathrm{ng} / \mathrm{mL}$ and it was almost twice following $30 \mathrm{mg}$ twice-weekly dose at $28 \mathrm{ng} / \mathrm{mL}$, indicating it is dose dependent. The $\mathrm{C}_{\min }$ at 336 hours $(25.2 \pm 12.4 \mathrm{ng} / \mathrm{mL})$ was similar to $\mathrm{C}_{\min }$ at day $80(24.2 \pm 4.8 \mathrm{ng} / \mathrm{mL})$, showing the steady-state concentration of the drug was achieved at fifth $30 \mathrm{mg}$ dose. ${ }^{15}$

Centchroman is widely distributed in the body due to its high-lipid solubility. The volume of distribution and drug clearance following a $30 \mathrm{mg}(\mathrm{Vd} / \mathrm{F}: 1328 \pm 458 \mathrm{~L}, \mathrm{Cl} / \mathrm{F}$ $6.35 \pm 1.8 \mathrm{~L} /$ hour $)$ or a $60 \mathrm{mg}$ dose $(\mathrm{Vd} / \mathrm{F}: 1077 \mathrm{~L} ; 1909 \mathrm{~L}$, $\mathrm{Cl} / \mathrm{F} 4.4 ; 7.6 \mathrm{~L}$ /hour) are comparable, suggesting that they are dose independent. ${ }^{19} 20$ One study on the distribution of centchroman in the endometrium, following a $30 \mathrm{mg}$ single dose, reports that centchroman is rapidly absorbed and distributed to the endometrium and at any given time, the concentration of centchroman in the uterus (mean: $152 \pm 39 \mathrm{ng} / \mathrm{g}$ ) is 1.93 times higher than the corresponding levels in the serum (mean: $55 \pm 13 \mu \mathrm{g} / \mathrm{L}$ ). ${ }^{24}$

Two clinical trials report the binding of centchroman to plasma proteins. ${ }^{25}{ }^{26}$ These show that centchroman binds strongly to serum albumin in healthy women. It has a low-affinity, high-capacity binding with a dissociation (Kd) rate constant of $13.19 \times 10^{-6} \mathrm{M}$. The binding increases with an increase in protein content. The trial by Khurana et al showed that with a method that includes dilution of serum, protein binding is found to be $95.2 \pm 1.1$ and $88.2 \% \pm 2.1 \%$ at 1 and $10 \mu \mathrm{g} / \mathrm{mL}$. While in method II, which is devoid of any dilution, protein-binding estimates were higher at $101.8 \pm 1.3$ and $94.9 \% \pm 3.6 \%$ at 1 and $10 \mu \mathrm{g} / \mathrm{mL}^{26}$

Centchroman is metabolised in the liver into active and inactive metabolites; the active metabolite (7-desmethyl centchroman) is responsible for anti-implantation effect. ${ }^{22}$

\section{In breastfeeding women}

Four clinical trials report pharmacokinetics of centchroman in breastfeeding women. ${ }^{27-30}$ These studies report the infant is exposed to a small percentage $(2.5 \%-$ $9.5 \%$ ) of the maternal dose of centchroman through breast milk. The $\mathrm{C}_{\max }$ in breast milk was higher $(70.7 \pm 27.5 \mu \mathrm{g} / \mathrm{L})$ than $\mathrm{C}_{\max }$ in the serum $(60.7 \pm 12.2 \mu \mathrm{g} / \mathrm{L})$, and the $\mathrm{T}_{\max }$ was attained later in the milk $(8.50 \pm 1.7$ hours $)$ than in the serum (6 hours). ${ }^{30}$

\section{Centchroman as postcoital contraceptive pill}

One RCT among 150 women reports the effectiveness of centchroman as postcoital pill within 120 hours of single unprotected intercourse. ${ }^{31}$ The aim of this trial was to compare the efficacy and side effects of two different centchroman regimens with $1.5 \mathrm{mg}$ single-dose levonorgestrel. In this trial, women were randomly allocated into three groups (50 women in each group). Women in group I received a $1.5 \mathrm{mg}$ single dose of levonorgestrel tablet, single $60 \mathrm{mg}$ dose for group II, and group III received one $30 \mathrm{mg}$ tablet, twice a day, at an interval of 12 hours. The side effects reported from groups I, II and III were menstrual delay $>7$ days $(6 \%, 6.2 \%, 2 \%)$, headache $(8 \%, 10.6 \%, 14.3 \%)$, abdominal pain $(2 \%, 6.3 \%$, $8.2 \%)$ and nausea $(14 \%, 4.3 \%, 4 \%)$, respectively, and $10 \%$ in group I reported dizziness. Four per cent in group I, $2 \%$ users in group II and $6 \%$ users in group III reported pregnancies, all classified as method failure (MF) (effectiveness $96 \%, 98 \%, 94 \%)$. This trial concluded that singledose centchroman regimen (group II) is well compared with single-dose regimen of levonorgestrel both in terms of efficacy and safety.

\section{Effectiveness of centchroman as a weekly contraceptive}

Eight studies (five clinical trials and three observational studies) included in the scoping review report the effectiveness of centchroman ${ }^{23}{ }^{32-38}$ (table 3). Effectiveness in the included studies was calculated from the number of pregnancies from MF. Any pregnancy associated with non-compliance of the drug is classified as user failure (UF).

\section{Clinical trials}

Four of these studies report the results from the phase III and phase IV trials on centchroman. The first study is a multicentric phase III clinical trial (until June 1984), conducted among 467 women across 10 family welfare centres. ${ }^{33}$ Centchroman was administered as a $30 \mathrm{mg}$ once-a-week tablet starting on the first day of the menses, and thereafter one tablet was taken on the same day every subsequent week. An additional tablet had to be taken on the first day of every subsequent menstrual cycle irrespective of the weekly tablet. Women had regular check-ups every month. The duration of centchroman use in this trial ranged from 1 to 36 months. A total of $19 \mathrm{MF}$ and 44 UF pregnancies occurred during the study duration (95.9\% effective). Of the $19 \mathrm{MF}$ pregnancies, 14 (73.7\%) occurred in the first 6 months of centchroman use and only $1(5.3 \%)$ after 1 year of drug use (Pearl Index 4.2). The 44 UF pregnancies occurred because the women did not adhere to the pill schedule, with 20 pregnancies (45.5\%) occurring in the first 6 months, 15 pregnancies $(34 \%)$ between 7 and 12 months and 9 pregnancies $(20.5 \%)$ after 1 year of pill use.

The second study is an extension of the phase III multicentric clinical trial, and reports the results in two parts: 
Table 3 Summary of studies on effectiveness of centchroman as a weekly contraceptive pill

\begin{tabular}{|c|c|c|c|c|c|c|}
\hline Ref* $^{*}$ & Dosage & Sample size & $\begin{array}{l}\text { Pearl } \\
\text { Index }\end{array}$ & $\begin{array}{l}\text { Method } \\
\text { failure }\end{array}$ & User failure & Effectiveness \\
\hline \multicolumn{7}{|c|}{ Clinical trials } \\
\hline \multirow[t]{2}{*}{32} & \multirow{2}{*}{$\begin{array}{l}30 \mathrm{mg} \text { once a week. First tablet on } \\
\text { first day of menses and thereafter } \\
\text { one tablet on that day every week. } \\
\text { One additional tablet was taken } \\
\text { on first day of every subsequent } \\
\text { menses irrespective of weekly tablet } \\
\text { (phase III). }\end{array}$} & 648 & 3.7 & $27(4.2 \%)$ & $66(10.2 \%)$ & $95.8 \%$ \\
\hline & & 100 & 1.2 & - & - & - \\
\hline 23 & $\begin{array}{l}30 \mathrm{mg} \text { twice a week for } 3 \text { months, } \\
\text { followed by } 30 \mathrm{mg} \text { once a week }\end{array}$ & 377 & 1.83 & $6(1.6 \%)$ & 24 (6.7\%) & $98.4 \%$ \\
\hline 3435 & $\begin{array}{l}30 \mathrm{mg} \text { twice a week for } 3 \text { months, } \\
\text { followed by } 30 \mathrm{mg} \text { once a week }\end{array}$ & $\begin{array}{l}755 \text { (out of } \\
934)\end{array}$ & n.a. & $20(2.6 \%)$ & - & $97.4 \%$ \\
\hline 37 & $\begin{array}{l}30 \mathrm{mg} \text { twice a week for } 3 \text { months, } \\
\text { followed by } 30 \mathrm{mg} \text { once a week }\end{array}$ & 27 & n.a. & \multicolumn{2}{|c|}{$\begin{array}{l}\text { Ineffective in two users } \\
(7 \%)\end{array}$} & $93 \%$ \\
\hline
\end{tabular}

${ }^{*}$ The complete study titles are in the reference section.

n.a., not applicable.

(A) phase III trial until November 1986 and (B) extended phase III clinical trial (April 1987 to November 1988). ${ }^{32}$ In the study (until 1986), 648 women were recruited from 10 family welfare centres. The dosage schedule of centchroman was same as the phase III trial. ${ }^{33}$ The duration of pill use ranged from 1 to 52 months. Twenty-seven MF and 66 UF pregnancies occurred in the study duration (95.8\% effective)/Pearl Index of 3.7. Among the 27 MF pregnancies, 19 (70\%) occurred in the first 5 months and $4(15 \%)$ occurred after 1 year of centchroman use. For the extended phase (April 1987 to November 1988), 100 women were recruited in five additional centres. The details of number of pregnancies in the extended phase are unavailable, however Pearl Index is reported as 1.2.

Phase IV clinical trial (postmarketing trial) was initiated in 2009, across 18 human reproductive research centres of ICMR, India. ${ }^{34}$ It was a non-randomised clinical trial, with $\mathrm{Cu}-\mathrm{T}$ users being the comparison group. The dosage schedule for phase IV was $30 \mathrm{mg}$ centchroman twice a week for 12 weeks, followed by once-weekly $30 \mathrm{mg}$ thereafter. The trial enrolled 2087 women (934 with centchroman and 1153 with $\mathrm{Cu}-\mathrm{T}$ ). The interim results of this phase (on 755 centchroman users) reveal $20 \mathrm{MF}$ pregnancies (97.4\% effective). The detailed results of this phase are neither published nor available on request.

One conference paper ${ }^{23}$ reports a clinical trial among 377 women to study the effectiveness of centchroman using the schedule: $30 \mathrm{mg}$ centchroman twice a week for 12 weeks followed by $30 \mathrm{mg}$ once a week. The study duration ranged from 1 to 27 months. Six MF and 24 UF pregnancies were reported during the study duration (effectiveness: 98.4\%). Of the six MF, 2 (33\%) failures occurred during the first month, $2(33 \%)$ at 3 months and $1(17 \%)$ each at 9 and 15 months.

\section{Observational studies}

Additionally, three observational studies report effectiveness of centchroman ranging from $93 \%$ to $100 \%$ (table 3). In the first study, 153 women were followed up for 12 months, of which 11 women became pregnant (4.6\% MF and $2.6 \%$ UF). Majority $(81 \%)$ of pregnancies occurred during the first 6 months while all occurred within 9 months of initiation of the pill. ${ }^{38}$

In the second study, 27 women were followed up for 8 months; effectiveness was $93 \% .{ }^{37}$ The authors did not report details of MF or UF. In the third study, 17 women were followed for 12 months; effectiveness was $100 \%{ }^{36}$

\section{SIDE EFFECTS OF CENTCHROMAN USE}

Thirteen studies ${ }^{17} 2331-33$ 36-43 report side effects from centchroman use as a weekly contraceptive pill (tables 4 and 5). We are reporting frequently reported side effects under the following headings: menstrual irregularities, other side effects and changes on ultrasound examination.

\section{Menstrual irregularities}

The most frequent side effect among centchroman users is menstrual irregularities like: short cycles lasting $<20$ days (reported by four studies; $4 \%, 5 \%, 3 \%, 8 \%$ users), ${ }^{23} 323340$ prolonged cycles $>45$ days (six studies; $8.8 \%, 10 \%, 10 \%$, $3 \%, 3.7 \%, 26 \%, 16 \%$ users) [ ${ }^{20} 2333363840$ scanty bleeding lasting 1 or 2 days (two studies; $12 \%, 36.7 \%$ users) ${ }^{36} 38$ and menstrual delay $>30$ days (one study; $15 \%$ users). ${ }^{40}$ Five studies report continuous bleeding as a side effect. Of 


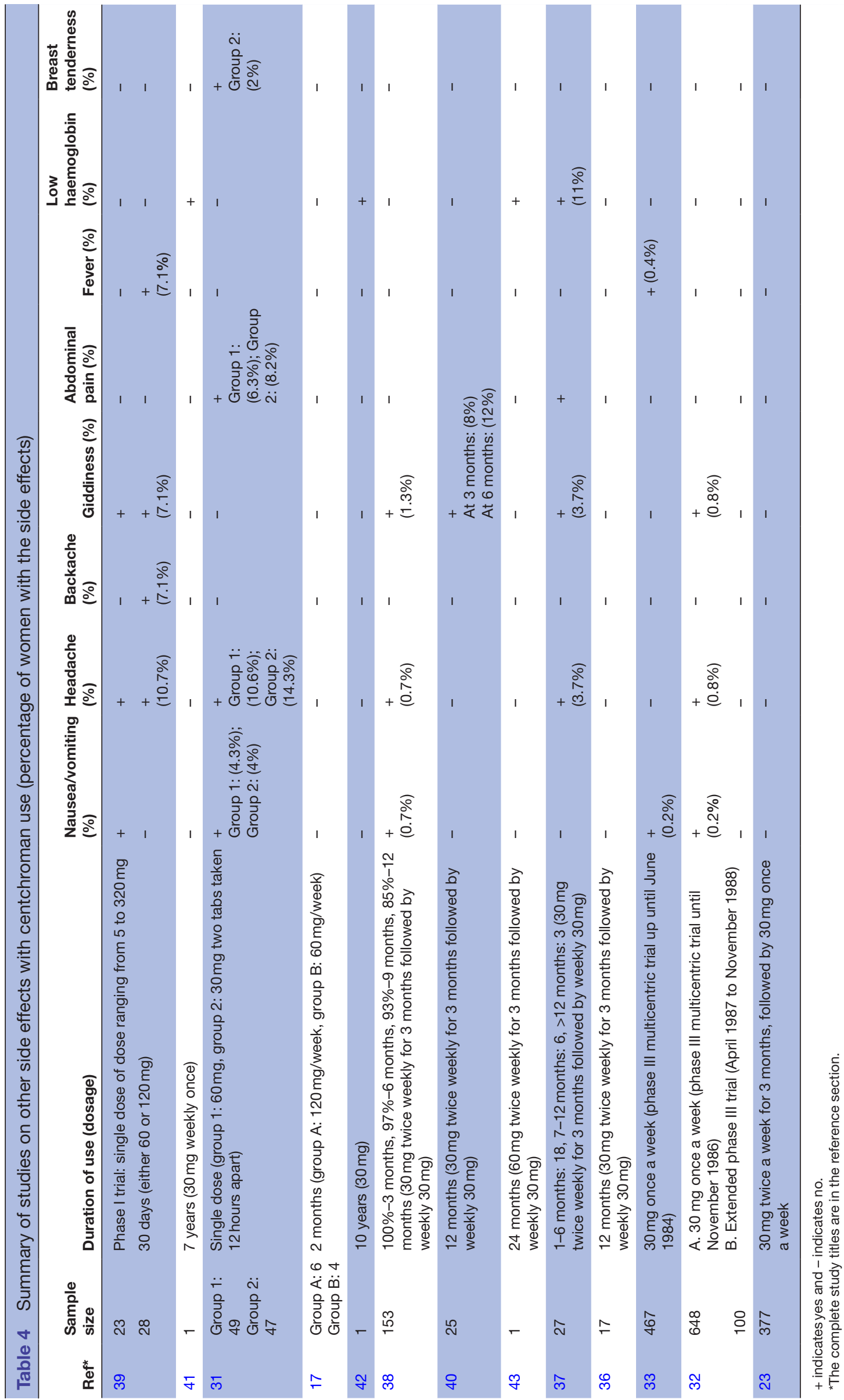




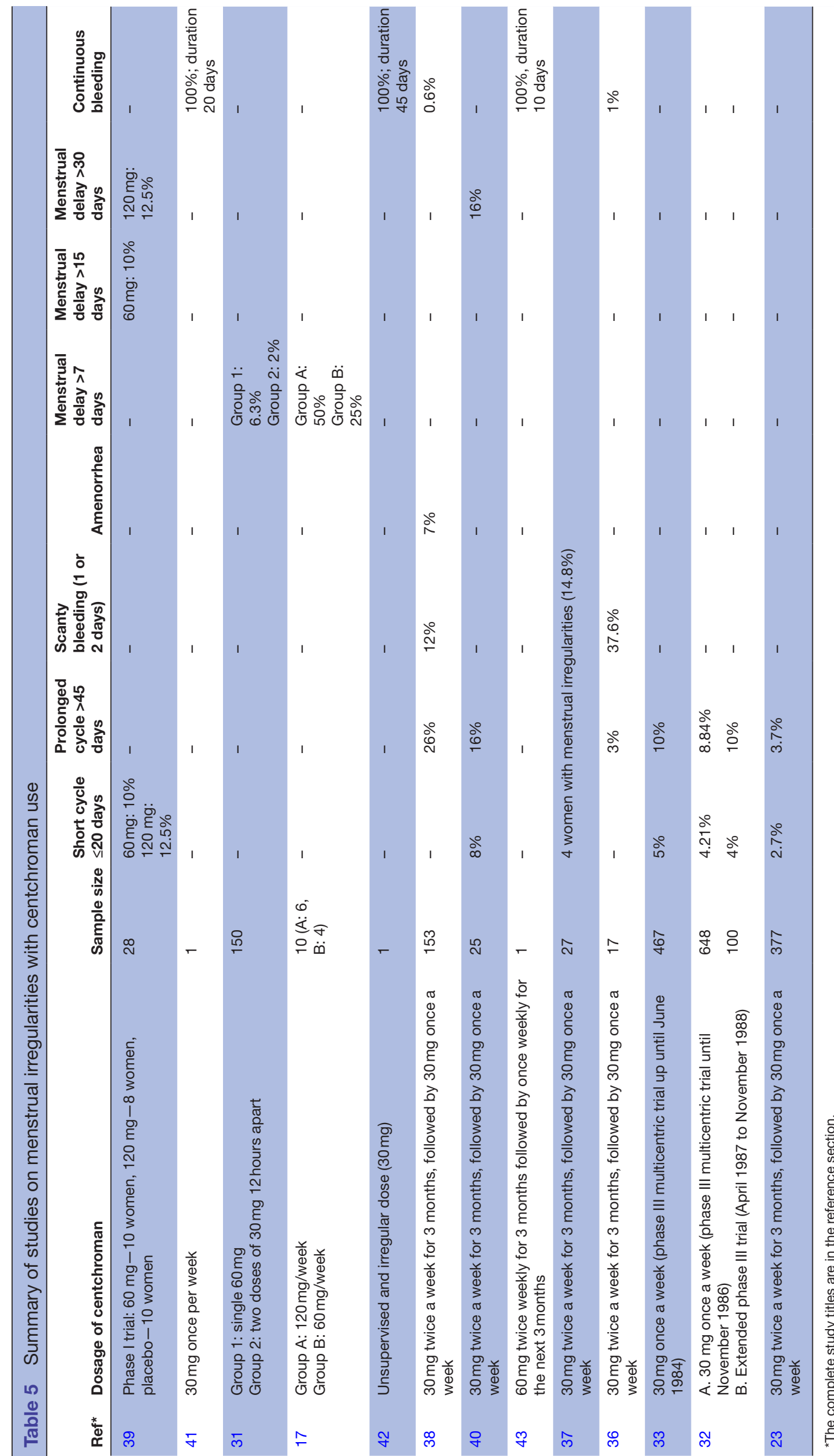

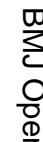

$\stackrel{\vec{F}}{\stackrel{\vec{D}}{+}}$

흘

$\stackrel{\mathbb{\Omega}}{\Omega}$

क

$\vec{\circ}$

$\overrightarrow{\vec{\omega}}$

응.

$\stackrel{\Phi}{9}$

กิำ

这

Wు

ㅇ

○

웅

옹

망

능

$\frac{0}{\mathbb{D}}$

옹

룽

के 
these, three are case reports of women on unsupervised long-term use of the pill, presenting with continuous bleeding of 10-45 days' duration. ${ }^{41-43}$ Two other studies report continuous bleeding among $1 \%$ of centchroman users. $^{36} 38$ The Indian national guidelines on oral contraceptive use report menstrual delay among $8 \%$ of centchroman users, and state it typically occurs in the first 3 months of centchroman use. ${ }^{4}$

\section{Other side effects}

The phase I trial on centchroman initiated in 1970s included 51 participants (23 females and 28 males). ${ }^{39}$ At the end of this phase, it was concluded that a dose of $5-320 \mathrm{mg}$ centchroman is well tolerated by humans, because it did not show any major side effect or any abnormality in laboratory parameters.

Phase III multicentric trials (until 1984) reported one woman with $8 \mathrm{~kg}$ weight gain over 34 months' period of drug use, one of loose stools, vomiting, and two with fever. ${ }^{33}$ In the phase III trial (until 1986), five women complained of giddiness, five of headache, one of anorexia, one of loose motions and vomiting and one ectopic pregnancy. ${ }^{32}$

The other side effects reported from included studies were: headache (two studies; $1 \%$ and $4 \%$ users) ${ }^{3738}$ giddiness (two studies; $1.3 \%$ and $12 \%$ ), ${ }^{37} 38$ nausea (one study,
$0.7 \%)^{38}$ and giddiness with abdominal pain (one study; $8 \%$ at 3 months and $12 \%$ users at 6 months).$^{40}$ In addition, three case reports provide detail on women with complaints of continuous bleeding and on investigation are found to be severely anaemic (Hb: $4 \mathrm{~g} / \mathrm{dL}, 5 \mathrm{~g} / \mathrm{dL}$ and $7 \mathrm{~g} / \mathrm{dL}) .{ }^{41-43}$ Further, an observational study reported anaemia in $11 \%$ users. $^{37}$

\section{Changes in the ovaries and uterus}

Seven studies $29353841-43$ in the review report the ultrasound findings among centchroman users (table 6). The main findings reported by these studies are: (A) three case reports found a bulky uterus with distorted endometrial cavity, ${ }^{41-43}$ and (B) one study found ovarian enlargement among $18 \%$ of the users. ${ }^{38}$ In another study among the 175 women who were followed up for 40 months on centchroman, $15 \%$ showed ovarian enlargement. The enlargement was unilateral, transient and never persisted and got resolved despite centchroman therapy. ${ }^{29}$ One study among 17 women, however, showed no changes in ovaries. ${ }^{36}$ The preliminary results of the phase IV trial report four women with ovarian cysts $<5 \mathrm{~cm}$ and two women with cysts $>5 \mathrm{~cm} .{ }^{35}$

Table 6 Summary of studies on ultrasound findings among centchroman users

\begin{tabular}{|c|c|c|c|c|}
\hline Ref* $^{*}$ & $\begin{array}{l}\text { Women who } \\
\text { underwent USG (n) }\end{array}$ & Dosage of centchroman & $\begin{array}{l}\text { Duration of } \\
\text { centchroman } \\
\text { intake }\end{array}$ & Ultrasound findings \\
\hline 41 & 1 & $30 \mathrm{mg}$ once a week & 7 years & $\begin{array}{l}\text { Enlarged uterus with well-delineated endometrial } \\
\text { thickness and a mixed echogenic collection in a } \\
\text { distorted endometrial cavity }\end{array}$ \\
\hline 42 & 1 & $\begin{array}{l}30 \mathrm{mg} \text { once a } \\
\text { week (irregular and } \\
\text { unsupervised) }\end{array}$ & 10 years & $\begin{array}{l}\text { Mixed echogenic collection in a distorted } \\
\text { endometrial cavity of a bulky uterus }(101 \times 84 \mathrm{~mm}) \\
\text { Ovaries were normal. }\end{array}$ \\
\hline 38 & $\begin{array}{l}28 \text { (of } 153 \\
\text { participants) }\end{array}$ & $\begin{array}{l}30 \mathrm{mg} \text { twice weekly for } 3 \\
\text { months, followed by } 30 \mathrm{mg} \\
\text { once weekly }\end{array}$ & 3-12 months & $\begin{array}{l}20 \text { women had normal-looking ovaries. } \\
4(14.2 \%) \text { women had follicular cysts. } \\
4(14.2 \%) \text { women had corpus luteal cysts. } \\
\text { No cyst was bigger than } 2.5-3 \mathrm{~cm} \text {. }\end{array}$ \\
\hline 43 & 1 & $\begin{array}{l}60 \text { mg twice weekly for } 3 \\
\text { months, followed by once } \\
\text { weekly (unsupervised use) }\end{array}$ & 2 years & $\begin{array}{l}\text { Bulky uterus with } 8 \times 4 \mathrm{~cm} \text { hyperechoic area with } \\
\text { increased AV channels within it } \\
\text { Endometrium was not separately made out. }\end{array}$ \\
\hline 23 & $\begin{array}{l}64 \text { (of } 377 \\
\text { participants) }\end{array}$ & $\begin{array}{l}30 \mathrm{mg} \text { twice a week for } 3 \\
\text { months, followed by } 30 \mathrm{mg} \\
\text { once a week }\end{array}$ & 12-30 months & $\begin{array}{l}\text { Two cases of enlarged ovaries } \\
\text { One showed enlarged ovary at } 6 \text { months and one at } \\
12 \text { months. } \\
\text { In both cases, enlargement was due to mature } \\
\text { unruptured follicle. } \\
\text { On subsequent examination at } 12 \text { and } 20 \text { months, } \\
\text { ovaries were normal. }\end{array}$ \\
\hline 29 & 175 & $\begin{array}{l}30 \mathrm{mg} \text { twice a week for } 3 \\
\text { months, followed by } 30 \mathrm{mg} \\
\text { once a week }\end{array}$ & $\begin{array}{l}\text { Up to } 40 \\
\text { months }\end{array}$ & $\begin{array}{l}15 \% \text { of women had ovarian enlargement. } \\
\text { Enlargement was unilateral and transient. }\end{array}$ \\
\hline
\end{tabular}

No additional data are available.

*The complete study titles are in the reference section.

AV channels, Arteriovenous channels; USG, ultrasonography. 


\section{DISCUSSION}

This is the first scoping review that systematically identified and summarised the studies on centchroman as a contraceptive pill. Our primary aim for this scoping review was to collate the overall evidence available on the current state of knowledge on mechanism of action, pharmacokinetics, side effects and effectiveness of centchroman as a weekly and postcoital contraceptive pill. The methods used throughout the different stages of the review were rigorous, transparent, and the process is documented in sufficient detail to replicate the research approach. In addition, we interviewed a product manager from the pharmaceutical company that manufactures centchroman in India to gain insight on sales and marketing of centchroman. He said that currently centchroman is only marketed in India as a weekly contraceptive pill, though in the past it has been sold as an emergency postcoital pill and was also marketed in South America for a short period. On effectiveness, with perfect use the failure rate of centchroman was $1 \%-2 \%$, but with typical use the failure rate increases to $6 \%-7 \%$. We here recognise the potential conflict of interest, as the pharmaceutical manager may be biased in responses to boost his company sales.

This scoping review identified 33 primary research papers, annual reports, theses and national guidelines on centchroman from India published between 1976 and 2019. Only two studies in our review report the mechanism of action of centchroman in women (sample size: 8,10$).{ }^{16} 17$

Eight studies report the effectiveness of centchroman as a weekly contraceptive pill involving a total of 2544 women. The reported effectiveness ranged from $96 \%$ to $98 \%$ in clinical trials and $93 \%$ to $100 \%$ in observational studies. This review thus suggests that the effectiveness of centchroman as a weekly contraceptive is slightly lower than what is noted as $98 \%-99 \%$ in the Indian national guidelines. ${ }^{4}$ Only one RCT among 150 women reports the effectiveness of centchroman as a postcoital pill. ${ }^{31}$ It was $98 \%$ effective when taken as a single $60 \mathrm{mg}$ within 120 hours of unprotected intercourse. The detailed results of phase IV trials would provide conclusive information on effectiveness.

Thirteen studies report side effects of centchroman use as an oral contraceptive. Continuous bleeding and prolonged cycles $>45$ days were the two most commonly reported side effects among centchroman users. The side effects profile is similar to that seen with hormonal contraceptive pills. The studies on side effects are of low quality with small sample size. The largest sample for observational studies was 153 women and maximum follow-up was of 12 months. This limits meaningful conclusions to be drawn. Though the phase IV drug trial included a large sample (934 users), but the detailed results of this phase are not published and were not available on request hence could not be used in the review. To the best of our knowledge there has been no published scientific trial comparing side effects of centchroman to other safe and effective contraceptive pill/oral contraceptives. There is a need for studies with robust study designs comparing centchroman to other hormonal methods.

The Indian national guidelines ${ }^{4}$ have menstrual delay among $8 \%$ of the centchroman users, and do not mention any other side effects. We suggest the guidelines be updated to include other side effects as well, so that the health providers can comprehensively counsel the women on the possible side effects during counselling.

\section{CONCLUSIONS}

Our scoping review provides a broad and a comprehensive review of currently available literature on centchroman when used as a contraceptive pill. The review demonstrates that despite evidence on effectiveness of centchroman, more research is needed on side effects and mechanism of action. Insufficient evidence exists on its use as a postcoital contraceptive pill. Robust study designs are needed such as RCT or longitudinal studies to compare effectiveness and safety of centchroman with other short-term modern contraceptives such as combined hormonal oral pills or progesterone only pills contraceptives. It is clear that there are extensive gaps in the literature that warrant further studies, both in Indian and international settings. The uncertainty and diversity of side effects and effectiveness in the studies across India implies a lack of body of evidence to make global recommendations on centchroman, a contraceptive method that is licensed and used in the second most populous country in the world.

Acknowledgements We thank Mr Tomas John Allen, librarian at WHO Geneva, for his assistance in developing a search strategy and running the search for this scoping review. We thank Drs Manisha Malhotra, Bulbul Sood, Saswati das (JHPIEGO) and Shalini Singh (ICMR) for their support in identifying the stakeholders and for their valuable suggestions on the protocol and the initial draft of this scoping review. We also thank all the stakeholders who participated in the interviews and shared their experiences with centchroman use.

Contributors The idea for this publication was conceived by RK and JK. RK and KPA prepared the first draft. MA, CAJ, KM and JK provided significant contributions to the draft. All authors reviewed the draft manuscript and approved the final manuscript for publication.

Funding The UNDP-UNFPA-UNICEF-WHO-World Bank Special Programme of Research, Development and Research Training in Human Reproduction (HRP), a cosponsored programme executed by the WHO, funded this work.

Disclaimer The funding sources did not play a role in the study design, analysis and interpretation of data, in the writing of the report, or in the decision to submit the article for publication. The conclusions and opinions expressed here are those of the authors and not necessarily those of the funder.

Competing interests None declared.

Patient consent for publication Not required.

Provenance and peer review Not commissioned; externally peer reviewed.

Data availability statement All data relevant to the study are included in the article

Open access This is an open access article distributed in accordance with the Creative Commons Attribution Non Commercial (CC BY-NC 4.0) license, which permits others to distribute, remix, adapt, build upon this work non-commercially, and license their derivative works on different terms, provided the original work is properly cited, appropriate credit is given, any changes made indicated, and the use is non-commercial. See: http://creativecommons.org/licenses/by-nc/4.0/.

ORCID iDs

Komal Preet Allagh http://orcid.org/0000-0002-6272-2135 
Moazzam Ali http://orcid.org/0000-0001-6949-8976

\section{REFERENCES}

1 Singh MM. Centchroman, a selective estrogen receptor modulator, as a contraceptive and for the management of hormone-related clinical disorders. Med Res Rev 2001;21:302-47.

2 Population Foundation of India. Spacing methods of family planning, 2014. Available: http://populationfoundation.in/files/fileattached/ Fileattached-1492415902-Family_Planning_methods_Eng.pdf [Accessed Cited 17th November 2017].

3 Kamboj VP, Ray S, Anand N. Centchroman a safe reversible postcoital contraceptive with curative and prophylactic activity in many disorders. Frontiers in Bioscience 2018;10:1-14

4 Family planning division. Ministry of health and family welfare, government of India. reference manual for oral contraceptive pills. New Delhi: Ministry of Health and Family welfare -Government of India, 2016.

5 Balasubramanian D. On conception and contraception: the story of Saheli; the Hindu: 24th June 2017. Available: https://www.thehindu. com/sci-tech/science/on-conception-and-contraception-the-storyof-saheli/article19140909.ece [Accessed Cited 28th June 2018].

6 Lal J. Clinical pharmacokinetics and interaction of centchroman - a mini review. Contraception 2010;81:275-80.

7 World Health Organization. WHO drug information: recommended inn list 34 international nonproprietary names for pharmaceutical substances. 8(4). Geneva: World Health Organization, 1994

8 Chawla PC. CSIR's novel contraceptive drug- a woman's true Saheli. In: Chawla PC, ed. CSIR news: progress, promise and prospects. New Delhi: NISCAR Press, 2010: 60 (15 \& 16). 171-2.

9 Population Research Institute. News from Latin America. One less weapon against the unborn: the abortion pill gets pulled from market. January 12010 . Population research Institute. Available: https:// www.pop.org/news-from-latin-america-one-less-weapon-againstthe-unborn-the-abortion-pill-gets-pulled-from-the-market/ [Accessed Cited 23rd November 2017].

10 HLL Lifecare Limited. Innovating for healthy generations. Annual report 2013-2014. Available: http://www.lifecarehll.com/page/render/ reference/Annual_Report [Accessed Cited 20th October 2017].

11 CSIR-Central Drug Research Institute. Centchroman. Available: http://cdri.res.in/centchroman.aspx [Accessed Cited 20th October 2017].

12 Hindustan Latex Family Planning Promotion Trust (HLFPPT). Tatkal-72. Available: https://hlfppt.org/tatkaal-72-contraceptive-pill/ [Accessed Cited 20th October 2017].

13 Arksey H, O'Malley L. Scoping studies: towards a methodological framework. Int J Soc Res Methodol 2005;8:19-32.

14 Peters MDJ, Godfrey CM, Khalil H, et al. Guidance for conducting systematic scoping reviews. Int J Evid Based Healthc 2015;13:141-6.

15 Lal J, Nityanand S, Asthana OP, et al. Multiple dose pharmacokinetics of centchroman in female volunteers. Indian $J$ Pharmacol 1998;30:120.

16 Roy S, Lakshmi Kumari G, Madoiya K, et al. Induction of ovulation in the human with centchroman: a preliminary report. Fertil Steril 1976;27:1108-10.

17 Vaidya R, Joshi U, Meherji P, et al. Activity profile of centchroman in healthy female volunteers. Indian J Exp Biol 1977;15:1173-6.

18 Central Drug Research Institute, Lucknow. Annual report 2016-17. Available: http://www.cdri.res.in/Annual Reports/Annual_Report 2016_17.pdf [Accessed Cited 21st October 2017].

19 Paliwal JK, Gupta RC, Grover PK, et al. High performance liquid chromatographic (HPLC) determination of centchroman in human serum and application to single-dose pharmacokinetics. Pharm Res 1989;06:1048-51.

20 Lal J, Asthana OP, Nityanand S, et al. Pharmacokinetics of centchroman in healthy female subjects after oral administration. Contraception 1995:52:297-300.

21 Lal J, Nityanand S, Asthana OP, et al. Comparative bioavailability of two commercial centchroman tablets in healthy female subjects. Indian J Pharmacol 1996;28:32-4.

22 Lal J, Nitynand S, Asthana OP, et al. Optimization of contraceptive

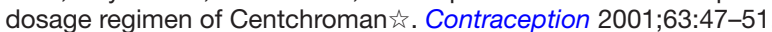

23 Nityanand S, Kamboj VP, Chandrawati, et al. Contraceptive efficacy and safety of centchroman with biweekly-cum- weekly schedule. In: Puri CP, VanLook PFA, eds. Current concepts in fertility regulation and reproduction. New Delhi: Wiley Eastern Ltd, 1994: 61-8.

24 Khurana M, Lal J, Kamboj M, et al. Uptake of centchroman by the human uterus. Clin Drug Investig 2002;22:715-8.

25 Srivastava AK, Agnihotri A, Kamboj VP. Binding of centchroman-a nonsteroidal antifertility agent to human plasma proteins. Experientia 1984;40:465-6.

26 Khurana M, Paliwal JK, Kamboj VP, et al. Binding of centchroman with human serum as determined by charcoal adsorption method. Int J Pharm 1999;192:109-14.

27 Paliwal JK, Grover PK, Asthana OP, et al. Excretion of centchroman in breast milk [letter]. Br J Clin Pharmacol 1994;38:485-6.

28 Gupta RC, Paliwal JK, Nityanand S, et al. Centchroman: a new non-steroidal oral contraceptive in human milk. Contraception 1995;52:301-5.

29 Nityanand S, Gupta RC, Kamboj VP. Centchroman: current status as a contraceptive. In: Dawn SC, ed. Centchroman: current status as a contraceptive. Indian progress in family welfare: clinical research on maternal and child health \& contraception. A Misra Calcutta: Dawn books, 1995: 26-31.

30 Gupta RC, Nityanand S, Asthana OP, et al. Pharmacokinetics of centchroman in nursing women and passage into breast milk. Clin Drug Investig 1996;11:305-9.

31 Mittal S, Sehgal R, Jindal VI, et al. Single dose levonorgestrel and two regimens of centchroman for emergency contraception. J Turk Ger Gynecol Assoc 2008;9:132-7.

32 Nityanand S, Singh L. Clinical evaluation of centchroman: a new oral contraceptive. Hormone antagonists for fertility regulation. In: Puri CP, VanLook PFA, eds. Indian Soc Study Reprod Fert. Bombay, 1988: 223-30.

33 Puri V, Kamboj VP, Chandra $\mathrm{H}$. Results of multicentric trial of Centchroman. In: Dhawan BN, ed. Pharmacology for health in Asia. New Delhi: Allied Publishers, 1988: 439-47.

34 Indian Council of Medical Research (ICMR). Reproductive health: annual report 2009-10. Available: http://www.icmr.nic.in/annual/ 2009-10/english/rh.pdf [Accessed Cited 20th November 2017].

35 Indian Council of Medical Research (ICMR). Reproductive health: annual report 2010-11. Available: http://www.icmr.nic.in/annual/ 2010-11/English\%20Annual\%20Report/rh.pdf [Accessed Cited 20th November 2017].

36 Tandon D. Effect of centchroman on biochemical profile, ovulation and ovarian size [Masters of Surgery Thesis]. Bundelkhand University, 1992. https://ia601601.us.archive.org/16/items/in.ernet. dli.2015.269787/2015.269787.Effect-Of.pdf

37 Ghosh S. Prospective observational study of the pattern of usage of oral contraceptive pills [Masters of Pharmacy thesis], 2014. http:// jadunivdspace.jdvu.ac.in/bitstream/123456789/29440/1/Acc.\% 20No.\%20DC\%201823.pdf

38 Nair HS, Jayasimhan P. A prospective study of centchroman users with special reference to its contraceptive benefit. $J$ Evid Based Med Healthcare 2016;3:5374-80.

39 Chandra H, Srimal RC, Kamboj VP, et al. Clinical pharmacology studies with centchroman. Indian J Exp Biol 1977;15:1170-2.

40 Agrawal P, Kushwa V, Mangal BK. Evaluation of safety profile of centchroman for contraceptive purpose. Natl J Med Allied Sci 2016;5:41-4

41 Malhotra KP, Sherpa M, Bhatia A. Centchroman: is unsupervised long-term use warranted? case report. Eur J Contracept Reprod Health Care 2011;16:403-6.

42 Agarwal R, Radhakrishnan G, Radhika AG, et al. Abnormal uterine bleed- an adverse event of long-term centchroman use? Indian J Mater Child Health 2014;16:1-7.

43 Padmaja A, Vemulapalli P, Jaya Prada Devi K. Rare case of endometrial hyperplasia following unsupervised prolonged use of Ormiloxifene. IOSR J Dent Med Sci 2013;5:55-7.

44 Family Planning Division. Ministry of health and family welfare, government of India. An update on new family planning methods for ASHA. New Delhi: Ministry of Health and Family welfare -Government of India, 2017.

45 Ministry of Health and family welfare, Government of India, United Nations Population Fund. Contraceptive updates. Reference manual for doctors. New Delhi: Ministry of Health and Family welfare, 2005 